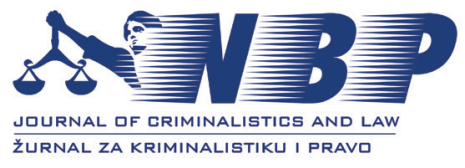

NBP 2021, Vol. 26, Issue 1, pp. 21-33

doi:10.5937/nabepo26-29725

Original scientific paper

\title{
Relationship of Anti-Money Laundering Index with GDP, Financial Market Development, and Human Development Index
}

\author{
${ }^{1}$ Mile M. Šikman ${ }^{1},{ }^{2}$ Miloš Grujić \\ ${ }^{1}$ University of Banja Luka, Faculty of Law, Banja Luka, Republic of Srpska \\ ${ }^{2}$ Independent University of Banja Luka, Faculty of Economics \\ Banja Luka, Republic of Srpska \\ Submitted: 2020-12-05 • Accepted: 2021-04-20 • Published: 2021-04-29
}

\begin{abstract}
Money laundering has a direct impact, among other things, on the economic development of a country. The aim of this research is to determine the correlation between money laundering and economic development expressed through GDP, as well as between financial market development (FDI) and the Human Development Index (HDI). The results of the research show that there was a significant relationship between the observed variables, i.e. that there is a relation of the Anti-Money Laundering Index (AMLI) on GDP, financial market development and the HDI. Namely, given that medium-strong links between the observed variables have been established, it can be claimed that there is reason to believe that "copying the behaviour" of a certain country in the fight against money laundering can further develop the financial market, influence human development or an increase in GDP per capita. In particular, a decrease in the AMLI was expected to increase the FDI ( $\mathrm{R}^{2}$ $=0.2601)$. A decrease in the AMLI was expected to increase the HDI $\left(\mathrm{R}^{2}=0.5747\right)$. In that way, financial institutions are directly affected, which negatively relates to economic and political stability.
\end{abstract}

Keywords: money laundering, Anti-Money Laundering Index, financial market development, Human Development Index, GDP (purchasing power) per capita.
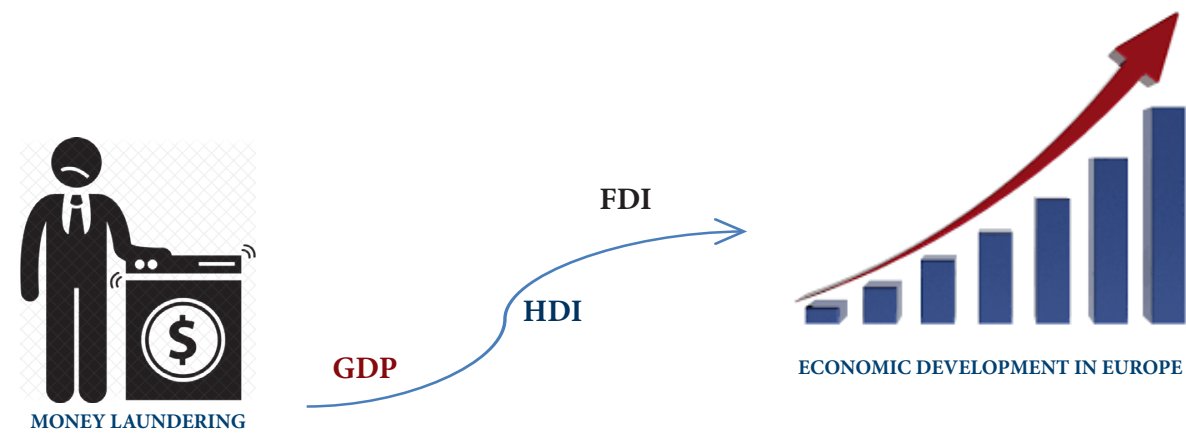

ECONOMIC DEVELOPMENT IN EUROPE

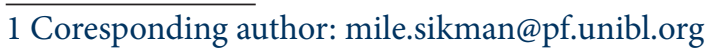




\section{INTRODUCTION}

Market globalization and money flows, on the one hand, and modern technologies and sophisticated payment manners on the other, open new possibilities and modify traditional manners of money laundering (Čudan, Ivanović \& Major, 2019, 44). Money laundering as a criminal phenomenon, although present for decades, is still not sufficiently researched. Contrary to popular belief, money laundering is found not to be associated with high costs, and can even generate significant profits (Teichmann, 2020). In addition to the fact that research on money laundering is conditioned by the type of approach (economic vs. legal approach) (Levi \& Soudijn, 2020), this phenomenon is also defined as a series of activities used to conceal income from criminal activity and present it as originating from legal activities (April \& Grasso, 2001). Money laundering is a derivative form of crime and is organically inseparably linked to other forms of crime, primarily organized crime and terrorism. The entrepreneurial model of international crime increasingly mimics the functioning of transnational companies (Šikman, 2011). Nowadays, the linkage of money laundering and terrorist financing arise as a global problem. Because of the continual development the mechanisms of money laundering and terrorist financing prevention can be smoothly avoided (Teichmann, 2019). Money laundering includes all types of post-criminal activities, traditionally oriented, such as offshore banking, smurfing, etc. (Salinger, 2005), or through cyber technologies (Vuković et al., 2016). Those activities aim at concealing illegal benefits or values acquired illegally by investing in the financial and non-financial system with the ultimate goal of laundering money (Tiwari et al., 2020). Financial Action Task Force on money laundering (FATF) defined money laundering as an alternation of criminal profit in order to camouflage their unlawful source (FATF, 2020). The consequences of money laundering are expressed in the economic and financial sector, especially in the banking sector, which further negatively affects not only social development, but also the political system (Vuković et al., 2011). Thus, according to the United Nations estimates, 2 to $5 \%$ of global GDP, or 800 billion to 2 trillion dollars, was laundered at the global level in one year. Although the difference between these figures is huge, even a lower estimate indicates the seriousness of the problem (UNODC, n. d.). This specifically means that there is a correlation between money laundering and GDP, i.e. the financial market, as well as human development in general. However, despite attempts to express the amounts of laundered money, it all comes down to estimates of the amount and number of launderers because it is a mysterious phenomenon and its scope is difficult to measure, especially because the most successful methods are still unknown (Jullum et al., 2020). Moreover, its simplified understanding seems to lead to the trivialization of this problem (Grujić \& Šikman, 2020).

The correlation between money laundering and economic development has been studied in previous research. Stancu and Rece (2009) found that the significance threshold of $8 \%$ of the volume of money laundered in the economy had a positive influence on economic growth (measured by the real GDP growth rate). Also, money laundering has positive effects on increasing the likelihood of achieving higher 
growth (Issaoui et al., 2017). This is because money returns to the legal economy after the laundering process, providing funds for investment and consumption, which consequently results in economic growth (Araujo \& Moreira, 2005; Stancu \& Rece, 2009). Although it has positive effects in short terms, there is no doubt that money laundering negatively affects economic growth in the long run (Tanzi, 1997). That is the reason why the benefits of only legal economy should not be questioned (Araujo \& Moreira, 2005). Similarly, Aluko and Bagheri (2012) pointed out that there was a positive relationship between corruption and money laundering in most countries and that countries affected by money laundering should cooperate more in order to mitigate these negative effects.

Examining the macroeconomic effects of money laundering, Idowu and Obasan (2012) concluded that money laundering negatively affects investment financing, government revenues, economic growth rates, and threatens the political stability and internal security of a nation. Some authors had also assessed the impact of financial development on economic growth, inequality and economic stability (Levine, 2004; Demirgüç-Kunt \& Levine, 2009; Dabla-Norris \& Srivisal, 2013). Financial development may also be measured by two financial depth parameters: the ratio of private loans to GDP and, to a lesser extent, and the capitalization of the stock market, also in relation to GDP (Aizenman et al., 2015; Čihák et al., 2012). For example, in an influential study at the industrial level, Rajan and Zingales (1998) used both measures to show that higher financial development facilitates economic growth. On the macroeconomic volatility side, Dabla-Norris and Srivisal (2013) stated that financial development, measured by private loans to the GDP of banks and other financial institutions, played a significant role in mitigating volatility in production, consumption and investment growth, but only to a certain extent. Most researchers in this field used variations of these measures to examine the role of the financial system in economic development (Mekinjić et al., 2019).

In order to overcome the shortcomings of certain indicators as a substitute for financial development, a multitude of indices have been created that show how developed financial institutions and financial markets are in terms of their depth, approach and efficiency, which culminates in the final Financial Development Index (FDI). The FDI was originally developed in the context of the International Monetary Fund (IMF) staff discussion note "Rethinking Financial Deepening: Stability and Growth in Emerging Markets" (Sahay et al., 2015). Compared to GDP, Human Development Index (HDI) has a greater emphasis on human development (Mekinjić et al., 2020). Some studies showed a high relationship between these two quantities (Natoli \& Zuhair, 2011; Shah, 2016). In order to shed more light on this issue, the Basel Anti Money Laundering Index (AMLI) should be introduced. Namely, the AMLI is the only independent research-based index issued by a non-profit organization, ranking countries according to their risk of money laundering and terrorist financing (REF). It provides risk scores based on the quality of a country's anti-money laundering and countering the financing of terrorism framework and related factors such as perceived levels of corruption, financial sector standards and public transparency. 
It is crucial to determine in which direction the correlation of the above mentioned parameters is moving. More specifically, it is paramount to examine the correlation between the AMLI and the achieved level of the market FDI, the achieved level of HDI and GDP (purchasing power) per capita (GDP PPP per capita). There has been some research on the topic of the impact of one trend, on the example of digitalization, on measures for the development of the economy and society (Mekinjić et al., 2020), but the connection between money laundering and these phenomena has not been examined. The primary reason for this is that money laundering is most often investigated as a criminal phenomenon, and although it and its consequences have been present for decades, they are still not sufficiently researched. Therefore, the aim of this study was to investigate whether the AMLI is associated with FDI and HDI. It was hypothesized that AMLI is significantly associated with both FDI and HDI.

\section{METHODOLOGY}

\section{Sample}

Given that the sample includes countries with very diverse economies (levels of risk of money laundering, GDP, etc.), efforts were made to focus the research on the countries from a more or less homogeneous climate. The sample was divided into subcategories, but values in each category, as a result of different levels of country development and other country characteristics, are still not homogeneous. In this regard, the focus was on the European countries for which the observed data exist. Analysing the amount of GDP PPP per capita by country, the countries were allocated into four groups: Western Europe, Southeast Europe, Eastern Europe, and the Western Balkans. Furthermore, the mean values were observed for the countries that are the members of the Organization for Economic Cooperation and Development (OECD) and those that are not the members (non-OECD countries).

\section{Variables}

The public edition of the Basel AMLI from 2019 was used for this study (Basel Institute of Governance, 2019). The Basel AMLI is a composite index, meaning it provides a simplified comparison of countries' risks of money laundering and terrorist financing (ML/TF). Each country's risk score is calculated from available data and does not represent an opinion or subjective assessment by the Basel Institute. In addition, the Index relies heavily on perception-based indicators such as the Transparency International Corruption Perceptions Index (TI CPI). In contrast to financial risk models based purely on statistical calculations, the Basel AML Index evaluates structural factors by quantifying regulatory, legal, political and financial indicators that influence countries' vulnerability to ML/TF.

The observed data was provided by the National Bureau of Economic Research (NBER, 2018), the Organisation for Economic Co-operation and Development 
(OECD, 2018), the World Economic Forum (WEF, 2018) and the GDP PPP per capita published by the International Monetary Fund (IMF, 2019). The data were downloaded from the official websites of these institutions.

For each observed country, the level of money laundering and its comparison with the FDI, HDI and GDP PPP per capita in 2018 were taken into account. The analysis included 125 countries, providing the sufficient data to calculate a reliable money laundering and terrorist financing risk score. The AMLI had been developed by the International Centre for Asset Recovery of the Basel Institute (ICAR, 2020). The $8^{\text {th }}$ edition of the AMLI was used for this study (Basel Institute of Governance, 2012). The expert edition interface, which includes a customizable interactive ranking and world map, covered 203 countries. Companies and financial institutions use this subscription-based service as a risk-rating tool for money laundering and terrorist financing for compliance and risk assessment purposes.

\section{Statistics}

This study describes the models and weak points of money laundering process, while respecting the standards and specifics of doing business in emerging markets. The processing of the obtained data includes sorting, i.e. sorting, categorizing, grouping and analysing the collected information. Pearson's correlation coefficient was used to investigate the correlation between the AMLI, FDI, HDI, and GDP PPP per capita. The association of the AMLI with FDI and HDI was calculated using the linear regression analysis. The significance level was set at $\mathrm{p}<0.05$. The magnitude of the correlation was defined as small $(\mathrm{r}=0.19-0.49)$, moderate $(\mathrm{r}=0.50-0.79)$, and large $(\mathrm{r}=0.8-1.0)$, while the power of prediction was defined as small $\left(\mathrm{R}^{2}=0.04\right.$ $0.25)$, moderate $\left(\mathrm{R}^{2}=0.26-0.64\right)$, and large $\left(\mathrm{R}^{2}=0.65-1.00\right)$ (Sullivan \& Feinn, 2012). The statistical procedures were conducted in SPSS version 20.0 (IBM, Chicago, IL).

\section{RESULTS}

The descriptive data for mean values of AMLI, FDI, HDI, and GDP PPP per capita for the European countries are shown in Table 1, for the European regions in Table 2, while the same data for the OECD and non-OECD countries are shown in Table 3.

The correlation analysis showed moderate associations between the investigated indicators (Table 4). 
Table 1. Average amounts of AMLI, FDI, HDI and GDP PPP per capita indicators for countries in Europe

\begin{tabular}{|l|c|c|c|c|c|}
\hline Country & AMLI & FDI & HDI & $\begin{array}{c}\text { GDP PPP } \text { per } \\
\text { capita }\end{array}$ & Region \\
\hline Luxembourg & 4.4 & 0.74 & 0.90 & 112.875 & EU Western Europe \\
\hline Ireland & 4.46 & 0.67 & 0.94 & 89.383 & EU Western Europe \\
\hline Netherlands & 4.56 & 0.73 & 0.93 & 57.101 & EU Western Europe \\
\hline Sweden & 3.32 & 0.77 & 0.93 & 52.477 & EU Western Europe \\
\hline Germany & 4.42 & 0.73 & 0.94 & 53.571 & EU Western Europe \\
\hline Austria & 4.38 & 0.65 & 0.91 & 55.406 & EU Western Europe \\
\hline Denmark & 3.46 & 0.65 & 0.93 & 57.781 & EU Western Europe \\
\hline Belgium & 3.98 & 0.65 & 0.92 & 50.114 & EU Western Europe \\
\hline Finland & 2.97 & 0.72 & 0.92 & 49.334 & EU Western Europe \\
\hline Italy & 4.61 & 0.77 & 0.88 & 40.066 & EU Southern Europe \\
\hline Malta & 5.48 & 0.56 & 0.88 & 43.087 & EU Southern Europe \\
\hline Spain & 3.66 & 0.86 & 0.89 & 38.143 & EU Southern Europe \\
\hline Sculptor & 4.81 & 0.55 & 0.87 & 39.079 & EU Southern Europe \\
\hline Slovenia & 3.35 & 0.37 & 0.90 & 38.506 & EU Southern Europe \\
\hline Portugal & 3.66 & 0.68 & 0.85 & 33.131 & EU Southern Europe \\
\hline Greece & 3.73 & 0.51 & 0.87 & 29.045 & EU Southern Europe \\
\hline Lithuania & 3.51 & 0.23 & 0.86 & 38.605 & EU Eastern Europe \\
\hline Estonia & 2.36 & 0.28 & 0.87 & 37.033 & EU Eastern Europe \\
\hline Poland & 4.36 & 0.47 & 0.87 & 33.739 & EU Eastern Europe \\
\hline Hungary & 4.99 & 0.41 & 0.84 & 32.434 & EU Eastern Europe \\
\hline Latvia & 4.62 & 0.26 & 0.85 & 30.579 & EU Eastern Europe \\
\hline Romania & 4.79 & 0.31 & 0.81 & 30.141 & EU Eastern Europe \\
\hline Bulgaria & 3.12 & 0.38 & 0.81 & 23.741 & EU Eastern Europe \\
\hline Croatia & 3.95 & 0.49 & 0.83 & 27.681 & Western Balkan \\
\hline Serbia & 5.47 & 0.25 & 0.79 & 18.840 & Western Balkan \\
\hline Albania & 5.69 & 0.19 & 0.79 & 13.651 & Western Balkan \\
\hline AMLI Ant & EU & E & & & \\
\hline
\end{tabular}

AMLI - Anti Money Laundering Index; FDI - Financial Development Index; HDI - Human Development Index; GDP PPP per capita - GDP (purchasing power) per capita.

Table 2. Average amounts of AMLI, FDI, HDI and GDP PPP per capita indicators for countries by regions

\begin{tabular}{|l|c|c|c|c|}
\hline Region & AMLI & FDI & HDI & GDP PPP per capita \\
\hline EU Western Europe & 4.03 & 0.70 & 0.92 & $64.226,89$ \\
\hline EU Southeast Europe & 4.19 & 0.61 & 0.88 & $37.293,86$ \\
\hline EU Eastern Europe & 3.96 & 0.33 & 0.84 & $32.324,57$ \\
\hline The Western Balkans & 5.04 & 0.31 & 0.80 & $20.057,33$ \\
\hline
\end{tabular}


Table 3. Average amounts of AMLI, FDI, HDI and GDP PPP per capita indicators for countries by groups

\begin{tabular}{|l|c|c|c|c|}
\hline Group & AMLI & FDI & HDI & GDP PPP per capita \\
\hline OECD & 4.13 & 0.61 & 0.89 & $46.028,93$ \\
\hline Non-OECD member country & 5.65 & 0.30 & 0.71 & $15.766,48$ \\
\hline
\end{tabular}

Table 4. Correlation of all four observed variables

\begin{tabular}{|l|c|c|c|}
\hline Variables & AMLI & FDI & HDI \\
\hline FDI & $-0.51^{\star *}$ & - & - \\
\hline HDI & $-0.76^{\star *}$ & $0.77^{\star *}$ & - \\
\hline GDP PPP per capita & $-0.53^{\star *}$ & $0.73^{\star *}$ & $0.79^{\star *}$ \\
\hline
\end{tabular}

${ }^{* *} p<0.01$.

The results of the liner regression show that there is a relationship between the AMLI and the FDI (Figure 1) and the AMLI and the HDI (Figure 2). There was a moderate relationship between the AMLI and the FDI, with $26.01 \%$ of the common variance. There was somewhat higher, but also moderate association between the AMLI and HDI, with $57.47 \%$ of the common variance. The beta coefficient for predicting the FDI was $-2.68(95 \% \mathrm{CI}=-3.60--1.76)$ and for predicting the HDI was $-6.99(95 \%$ $\mathrm{CI}=-8.21--5.77)$.

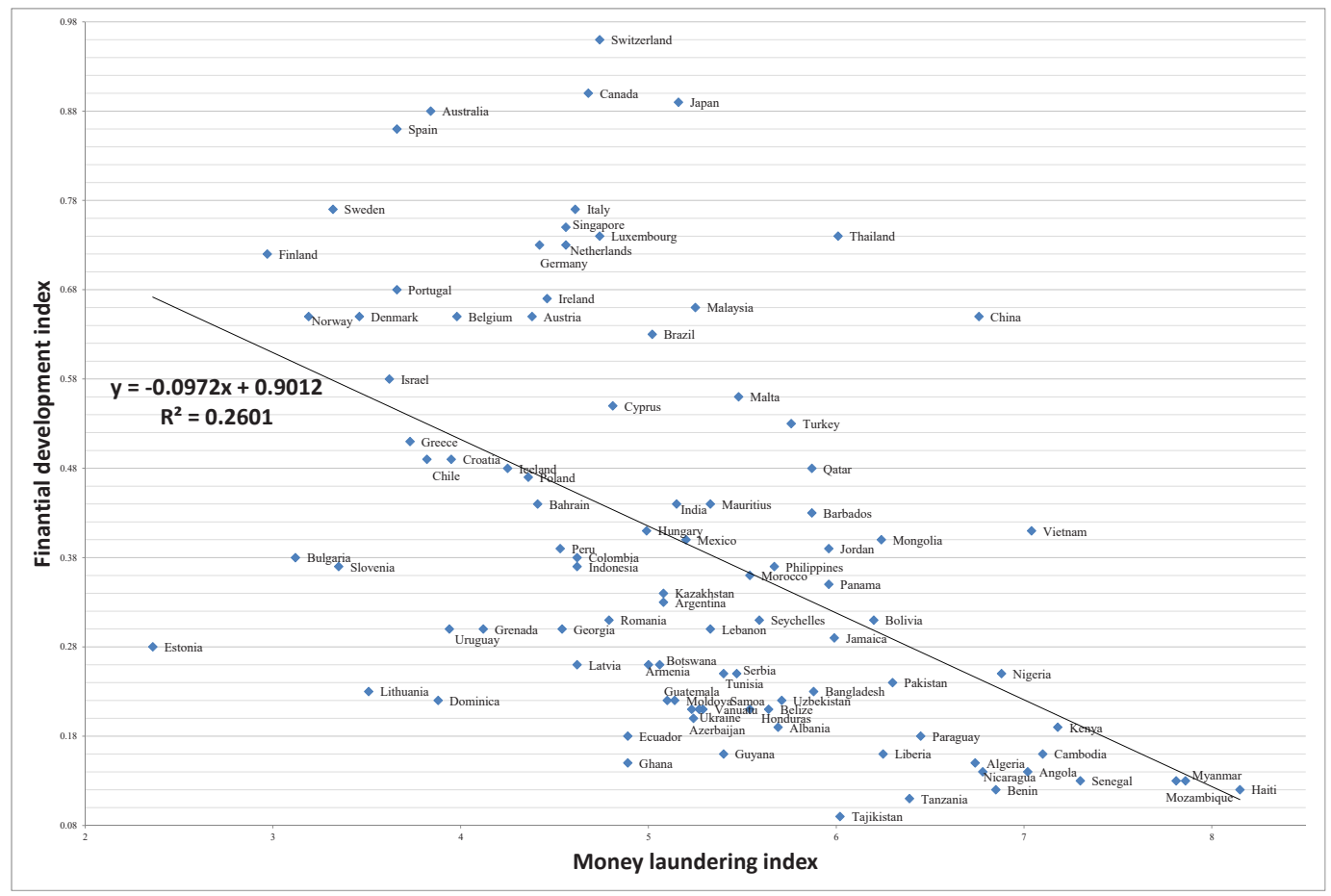

Figure 1. The linear regression between the AMLI and the FDI 


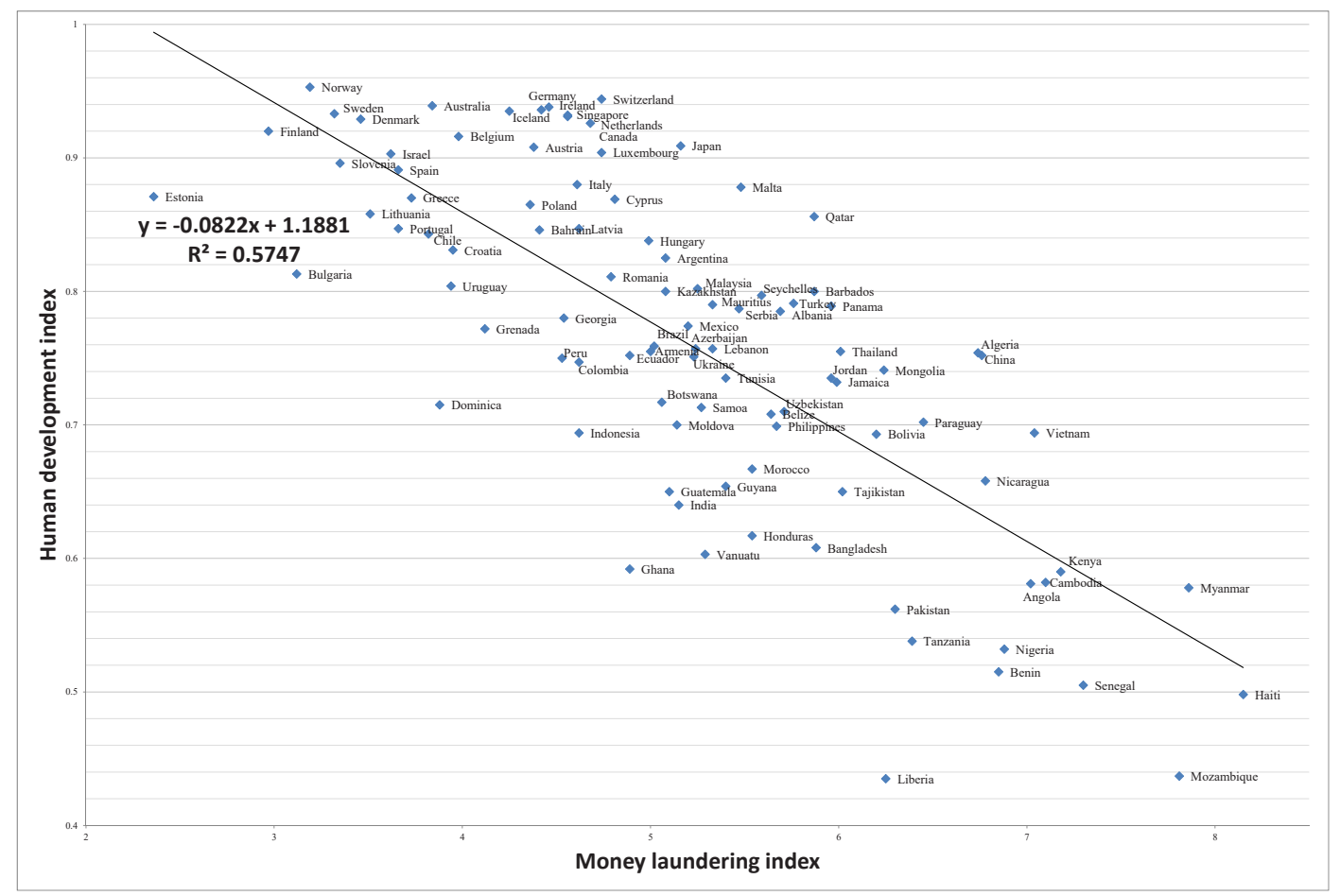

Figure 2. The linear regression between the AMLI and the HDI

\section{DISCUSSION}

Contemporary civilization flows bring characteristic security challenges taking into consideration that new threats are also developing on a daily basis, such as various forms of economic destruction which include money laundering (Čudan et al., 2019). By identifying concrete relations this study's findings investigated the associations between the AMLI, FDI, HDI, and GDP PPP per capita, as well as whether higher AMLI is associated with lower FDI and HDI. The results suggested a significant relationship between the level of money laundering and the development of the financial market, human development, and GDP PPP per capita. Moreover, there was a significant linear association of AMLI with FDI and HDI. Therefore, the hypothesis of this research was true.

The regression coefficient was larger in predicting the HDI than the FDI. Although in general coefficient of regression was negative for AMLI, one could argue that money laundering may have some positive effects on the financial development as well. In contrast, the human development was affected by money laundering almost to a large degree. Considering this and the large emigration rates in countries with higher AMLI, it could be argued that high rate of money laundering may be among the leading factors for a long-term emigration of capable and educated people who are seeking for personal development and more just system.

The fight against criminal economy is directly related to the problem of measures, instruments, and institutions competent for the fight against shadow economy. Grey 
economy and money laundering are problems that heavily burden underdeveloped countries (Nikolić et al., 2016). The Western Europe countries had, on average, about 20\% lower AMLI than the Western Balkans countries. At the same time, the countries of the Western Balkans had, 100\% higher FDI, while slightly less dramatic difference could be observed in terms of the HDI. Finally, the GDP PPP per capita of the Western Balkans countries and Western Europe countries was 1:3.2 to be more precise. Similarly, considering the OECD and non-OECD countries, the OECD countries had a lower mean AMLI and higher mean FDI and HDI and GDP PPP per capita.

Although GDP is not the only indicator that says everything about a country's economy and strength, it is used as a very good indicator of the general image of an economy. It has been shown that GDP has a solid correlation with AMLI, FDI and HDI. Therefore, GDP can indeed be used as a general indicator of the "health" of an economy, but it should not be used without a relationship with indicators such as employment and unemployment rates, real wages, inflation, productivity, living conditions, education, etc. After all, GDP is neither designed for that purpose nor can such an indicator exist.

Although the AMLI indicator suggested a strong correlation between GDP PPP per capita, FDI and HDI, some countries performed better than countries with similar or higher GDP. Thus, GDP PPP per capita showed a country's potential for combating money laundering, improving financial market performance, and the quality of life in a country. However, it did not show how much a country actually invested in these indicators. Regardless, it was obvious that there was a positive relationship as when GDP PPP per capita grew, the country's result also improved. The results showed that there was a significant relationship between GDP PPP per capita and the observed variables.

Further research should go in the direction in which it is necessary to investigate whether the financial investment in the fight against money laundering has an effect or to what extent the financial investment has an effect on the results of the observed variables. Similarly, further research should go in the direction where it is investigated which investments give the best result in increasing the level of financial market development and human development. Accordingly, further research should go in the direction of the relationship of the AMLI with other indicators, as well as expanding the topic by researching the impact of money laundering levels on the result of the FDI levels and money laundering levels of the HDI. The discussion could be supplemented with a brief review of the disadvantages and limitations - for example, significantly better results could be obtained by introducing a time dimension, i.e. by analysing panel data whose dimensions are state-year. For example, only the data from 2018 have been observed. This is the last year for which the data are available. Conclusions based on the research results from only one year may be questioned. Therefore, for further researches, a longer period of time and other measures for the development of the economy and society should be taken. 


\section{CONCLUSION}

The data used in research refer to 125 countries with very diverse economies (levels of risks of money laundering, GDP, etc.). Given that we have identified a moderate relationship between the observed variables, the impact of research results gives reason to believe that "copying the behaviour" of a country in the fight against money laundering can further develop the financial market, affect human development or increase GDP PPP per capita. The benefit of this conclusion should encourage the commitment of decision-makers in the country to a brave fight against money laundering. The reason for this is the fact that countries that represent a "fertile ground" for money laundering and terrorist financing have a low level of observed indicators. The paper represents contribution to the theory and application of economics, as well as to the wider public. The research results also indicate that it would be rational for economical decision-makers in developing countries to consider changing their models and new possibilities for their adjustment in the fight against money laundering. Given the demonstrated relation between money laundering and other indicators, it is of great importance to emphasize the need to eliminate the constraints and other limiting factors that affect the further fight against money laundering.

\section{REFERENCES}

Aizenman, J., Jinjarak, Y., \& Park, D. (2015). Financial development and output growth in developing Asia and Latin America: A comparative sectoral analysis. NBER Working Papers, 20917. National Bureau of Economic Research, Inc. https://www. nber.org/system/files/working_papers/w20917/w20917.pdf

Aluko, A., \& Bagheri, M. (2012). The impact of money laundering on economic and financial stability and on political development in developing countries: The case of Nigeria. Journal of Money Laundering Control, 15(4), 442-457. https://doi. org/10.1108/13685201211266024

April, D. H., \& Grasso, A. M. (2001). Money laundering. American Criminal Law Review, 38(3), 1051-1080.

Araujo, R. A., \& Moreira, T. B. (2005). An inter-temporal model of dirty money. Journal of Money Laundering Control, 8(3), 260-262. https://doi. org/10.1108/13685200510700552

Basel Institute of Governance. (2012). The Basel AML Index 2012. Basel Institute of Governance. https://baselgovernance.org/publications/basel-aml-index-2012

Basel Institute of Governance. (2019). The Basel AML Index 2019: A country ranking and review of money laundering and terrorist financing risks around the world. Basel Institute of Governance. https://baselgovernance.org/sites/default/files/2019-10/ Basel\%20AML\%20Index\%208\%20edition.pdf

Čihák, M., Demirgüç-Kunt, A., Feyen, E., \& Levine, R. (2012). Benchmarking financial systems around the world. Policy Research Working Paper, 6175. The World 
Bank. https://www.researchgate.net/publication/255697804_Benchmarking_Financial_Systems_Around_the_World

Čudan, A., Ivanović, Z., \& Major, G. (2019). Legalization of criminal profit in the course of agricultural privatization: A view from the Republic of Serbia. NBP. Nauka, bezbednost, policija, 24(3), 43-58. https://doi.org/10.5937/nabepo24-22958

Dabla-Norris, M. E., \& Srivisal, M. N. (2013). Revisiting the link between finance and macroeconomic volatility. IMF Working Papers, 13/29. https://www.imf.org/en/Publications/WP/Issues/2016/12/31/Revisiting-the-Link-Between-Finance-and-Macroeconomic-Volatility- 40284.

Demirgüç-Kunt, A., \& Levine, R. (2009). Finance and inequality: Theory and evidence. NBER Working Paper Series, 15275. National Bureau of Economic Research. https://www.nber.org/system/files/working_papers/w15275/w15275.pdf

Financial Action Task Force on Money Laundering [FATF]. (2020). What is money laundering? Financial Action Task Force. https://www.fatf-gafi.org/faq/moneylaundering/

Grujić, M., \& Šikman, M. (2020). Certain manifestation forms and proving money laundering in the emerging market. Acta Economica, 18(32), 175-201. https://doi. org/10.7251/ACE2032175G

Idowu, A., \& Obasan, K. A. (2012). Anti-money laundering policy and its effects on bank performance in Nigeria. Business Intelligence Journal, 5(2), 367-373.

International Centre for Asset Recovery [ICAR]. (2020). Basel AML Index 2019: $A$ country ranking and review of money laundering and terrorist financing risks around the world. https://baselgovernance.org/sites/default/files/2019-08/Basel\%20 AML\%20Index\%202019.pdf

International Monetary Fund [IMF]. (2019). Real per capita GDP growth. https:// www.imf.org/external/datamapper/NGDPDPC@WEO/OEMDC/ADVEC/WEOWORLD

Issaoui, F., Hassen, T., \& Wassim, T. (2017). The effects of money laundering (ML) on growth application to the Gulf countries. International Journal of Cyber Warfare and Terrorism, 7(1), 13-24. https://doi.org/10.4018/IJCWT.2017010102

Jullum, M., Løland, A., Huseby, R. B., Ånonsen, G., \& Lorentzen, J. (2020). Detecting money laundering transactions with machine learning. Journal of Money Laundering Control, 23(1), 173-186. https://doi.org/10.1108/JMLC-07-2019-0055

Levi, M. (2020). Evaluating the control of money laundering and its underlying offences: The search for meaningful data. Asian Journal of Criminology, 15(2), 301320. https://doi.org/10.1007/s11417-020-09319-y

Levi, M., \& Soudijn, M. (2020). Understanding the laundering of organized crime money. Crime and Justice, 49, 579-631. https://doi.org/10.1086/708047

Levine, R. (2004). Finance and growth: Theory and evidence. NBER Working Paper Series, 10766. National Bureau of Economic Research. https://www.nber.org/system/files/working_papers/w10766/w10766.pdf 
Mekinjić, B., Grujić, M., \& Vujičić-Stefanović, D. (2019). Primjena regresione analize u procjeni uticaja digitalizacije i tehnoloških inovacija na tri mjere razvoja privrede i društva. Bankarstvo, 48(4), 12-43.

Mekinjić, B., Grujić, M., \& Vujičić-Stefanović, D. (2020). Uticaj digitalizacije i tehnoloških inovacija na finansijskom tržištu na razvijenost finansijskog tržišta. Ekonomika preduzeća, 68(3-4), 269-279.

National Bureau of Economic Research [NBER]. (2018). International finance and macroeconomics catalogue of data sources. https://www.nber.org/data/international-finance/FinDev.xlsx

Natoli, R., \& Zuhair, S. (2011). Measuring progress: A comparison of the GDP, HDI, GS and the RIE. Social Indicators Research, 103(1), 33-56.

Nikolić, Đ., Čudan, A., \& Đorđević, B. (2016). Customs service in the function of the fight against shadow economy. NBP. Nauka, bezbednost, policija, 21(2), 159-180. https://doi.org/10.5937/nbp1602159N

Organisation for Economic Co-operation and Development [OECD]. (2018). Survey of large pension funds and public pension reserve funds. http://www.oecd.org/daf/ fin/private-pensions/survey-large-pension-funds.htm.

Quirk, P. J. (1996). Macroeconomic implications of money laundering. Working Paper No. 96/66. Washington, DC: International Monetary Fund.

Rajan, R., \& Zingales, L. (1998). Financial development and growth. American Economic Review, 88(3), 559-586.

Sahay, R., Čihák, M., N’Diaye, P., \& Barajas, A. (2015). Rethinking financial deepening: Stability and growth in emerging markets. Revista de Economía Institucional, 17(33), 73-107.

Salinger, L. M. (Ed.). (2005). Encyclopedia of white-collar \& corporate crime (Vol. 1). SAGE Publications.

Shah, S. (2016). Determinants of human development index: A cross-country empirical analysis. MPRA Paper, 73759. University Library of Munich.

Šikman, M. (2011). Organizovani kriminalitet. Visoka škola unutrašnjih poslova.

Stancu, I., \& Rece, D. (2009). The Relationship between economic growth and money laundering: A linear regression model. Theoretical and Applied Economics, 9(538), 3-8.

Sullivan, G. M., \& Feinn, R. (2012). Using effect size-or why the P value is not enough. Journal of Graduate Medical Education, 4(3), 279.

Tanzi, V. (1997). Macroeconomic implications of money laundering. In E. U. Savona (Ed.), Responding to money laundering: International perspective (pp. 91-104). Harwood Academic Publishers.

Teichmann, M. F. (2019). Recent trends in money laundering and terrorism financing. Journal of Financial Regulation and Compliance, 27(1), 2-12. https://doi. org/10.1108/JFRC-03-2018-0042 
Teichmann, F. (2020). Recent trends in money laundering. Crime, Law and Social Change, 73(2), 237-247.

Tiwari, M., Gepp, A., \& Kumar, K. (2020). A review of money laundering literature: The state of research in key areas. Pacific Accounting Review, 32(2), 271-303. https:// doi.org/10.1108/PAR-06-2019-0065

United Nation Office on Drugs and Crime [UNODC]. (n.d.). Money-laundering and globalization. https://www.unodc.org/unodc/en/money-laundering/globalization.html Vuković, S., Mijalković, S., \& Bošković, G. (2011). Prevencija pranja novca i finansiranja terorizma: osnovne metode i mogućnosti. NBP. Nauka, bezbednost, policija, 16(2), 117-131.

Vuković, S., Mijalković, S., \& Bošković, G. (2016). Police role in local crime prevention: Experiences from Serbia. In G. Meško, \& B. Lobnikar (Eds.), Criminal justice and security in Central and Eastern Europe (pp. 117-127). Faculty of Criminal Justice and Security.

World Econimic Forum [WEF]. (2018). Readiness for the future of production report 2018. http://www.weforum.org 
